\title{
A new distributional record of bladderwort species Utricularia janarthanamii for Gujarat state
}

\author{
Kamlesh Gadhvi ${ }^{1}$, Sandip Gamit ${ }^{1}$, Dushyant Dudhagara ${ }^{1}$, Suhas Vyas ${ }^{1^{*}}$ \& Rashmi Yadav $^{2}$ \\ ${ }^{1}$ Department of Life Sciences, Bhakta Kavi Narsinh Mehta University, Junagadh, Gujarat, India \\ ${ }^{2}$ St. Xavier's College (Autonomous), Ahmedabad, Gujarat, India \\ *Email:vsuhas.13@gmail.com
}

\author{
ARTICLE HISTORY \\ Received: 02 December 2020 \\ Accepted: 23 January 2021 \\ Published: 07 February 2021 \\ KEYWORDS \\ New record; Lantibulariaceae; \\ Girnar; Gujarat flora
}

\section{ABSTRACT}

We report the first distributional record of Utricularia janarthanamii S.R. Yadav, Sardesai \& S.P. Gaikwad from Girnar of Saurashtra region, Gujarat state. Saurashtra region comprises a wide variety of biological diversity as it consists of sandy, coastal and rocky habitats. The morphology and ecology of this species are described in this paper. This study adds new information on the flora of Gujarat and extended the distribution of this species in the Girnar mountain region.

\section{Introduction}

The bladderwort, genus Utricularia L. belongs to the family Lentibulariaceae, that comprises of terrestrial annual carnivorous plants. Taylor (1) in his monograph reported 214 species while Fleischmann (2) reported 228 species in the world. In India, Utricularia is represented by 41 species $(3-8)$. There are seven taxa of Utricularia reported from the Gujarat state, viz., U. arcuata Wt., U. aurea Lour., $U$. caerulea L., U. gibba subsp. exoleta (R.Br.) P.Taylor, $U$. reticulata Sm., U. stellaris L.f., $U$. striatula Sm. (9-11). Of these, three species $U$. stellaris L.f., $U$. reticulata Sm. and $U$. striatula Sm. have been reported from Saurashtra (12). During the recent field survey in the Girnar hills Jungadh district, which is considered to be one of the richest diversity sites in the state of Gujarat, an uncertain bladderwort was collected from Lal Dhori situated in Girnar hills, Gujarat. Detailed examination of this bladderwort is identified as Utricularia janarthanamii S.R.Yadav, Sardesai \& S.P. Gaikwad (7), hitherto unrecorded for the state. Hence, a detailed account of the species is presented here with photographs for easy identification. Voucher specimens (BKNMU015) are deposited at Department of Life Sciences, Bhakta Kavi Narsinh Mehta University, Junagadh, Gujarat.

\section{Taxonomic Treatment}

Utricularia janarthanamii S.R. Yadav, Sardesai \& S.P. Gaikwad in Rheedea 10(2): 107. 2000.

Herbs; Stem green, herbaceous, $6 \mathrm{~cm}$ high, rhizoids $2.5 \mathrm{~cm}$ long, branched, glandular; stolons 10 $\mathrm{cm}$ long, profusely branched. Leaves $0.5-2 \times 1-5 \mathrm{~mm}$ wide, spathulate, rounded at apex, scattered along stolons, 3- nerved, nerves branched. Traps on leaves large and elsewhere small, subglobose; stalk upto 1 mm long; mouth basal with two simple, subulate, glandular appendages; glands on appendages stalked and elsewhere sessile. Flowers in racemes on peduncle and solitary on leaves and stolons; peduncles $10 \mathrm{~cm}$ long, angular, grooved on one side, glabrous; scales basifixed, 1-nerved, acute at apex; pedicels 0.4$0.8 \mathrm{~cm}$ long. Calyx lobes unequal; upper lobe $2 \times 1.2$ $\mathrm{mm}$, ovate, acute or minutely dentate at apex; lower lobe $2 \times 1.3 \mathrm{~mm}$, ovate- elliptic, obtuse or minutely dentate at apex. Corolla blue to pink; upper lip $3.2 \times 1.1$ $\mathrm{mm}$, linear-oblong, crested at centre, rounded or notched at apex; lower lip 3-3.2 × 3.8- $4.2 \mathrm{~mm}$, obovate, hairy in throat, bigibbous at base, rounded at apex; spur 2-5 mm long; conical, descending, acute or 2-3 dentate at apex. Stamens 2, filaments strapshaped, slightly curved. Pistil 0.9-1.1 mm long, dorsally compressed; style short, distinct, flat; stigma

(c) Gadhvi et al (2021). This is an open-access article distributed under the terms of the Creative Commons Attribution License, which permits unrestricted use, distribution and reproduction in any medium, provided the original author and source are credited (https://creativecommons.org/licenses/by/4.0/).

To cite this article: Gadhvi K, Gamit S, Dudhagara D, Vyas S, Yadav R. A new distributional record of bladderwort species Utricularia janarthanamii for Gujarat state. Plant Science Today. 2021;8(1):182-184. https://doi.org/10.14719/pst.2021.8.1.1046 
2-lipped, truncate at apex. Capsules $1.8 \times 1.3 \mathrm{~mm}$, obliquely ovoid, wall uniformly membranous. Seeds numerous, subglobose, $0.5 \mathrm{~mm}$ across; testa cells more or less isodiametric (Fig. 1).

Flowering and Fruiting: August - November.
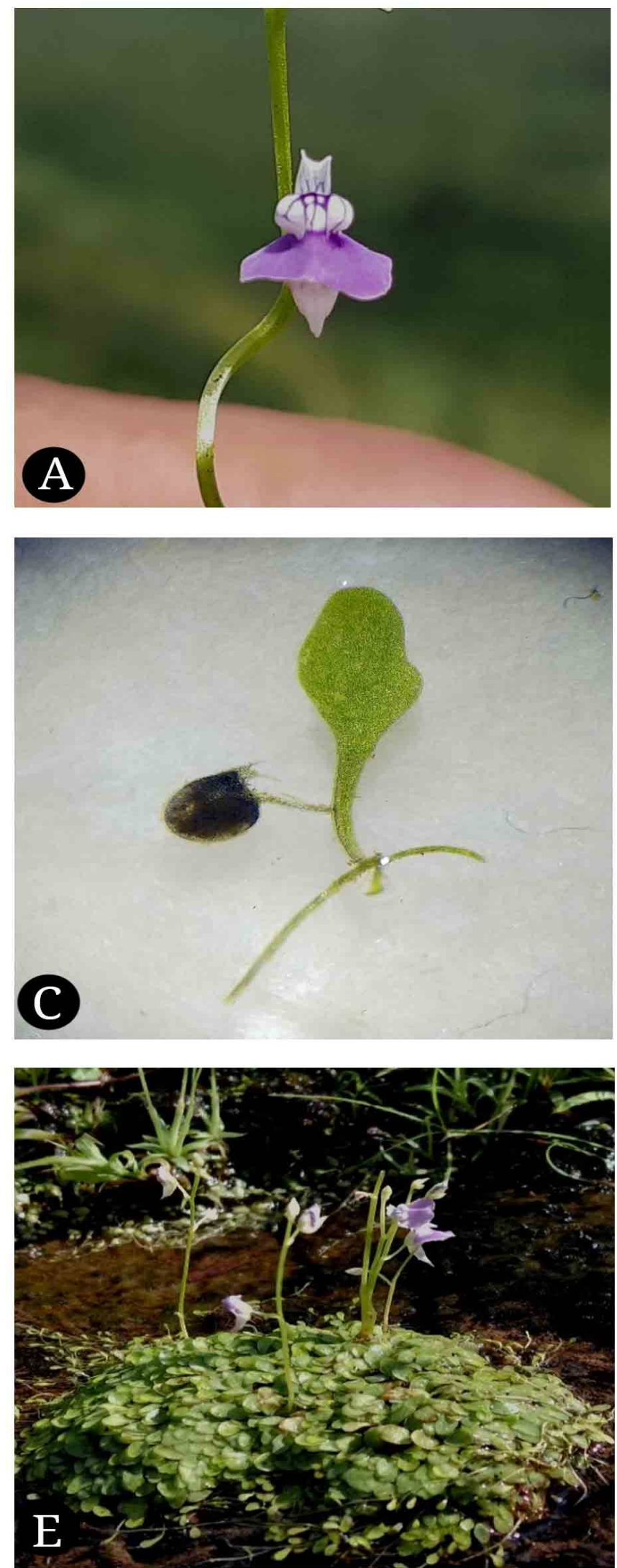

Fig. 1. Utricularia janarthanamii S.R. Yadav, Sardesai \& S.P. Gaikwad, A-B. Flower, C.Bladder with leaf, D. Seeds, E. Plant with habitat, F. Whole plant.

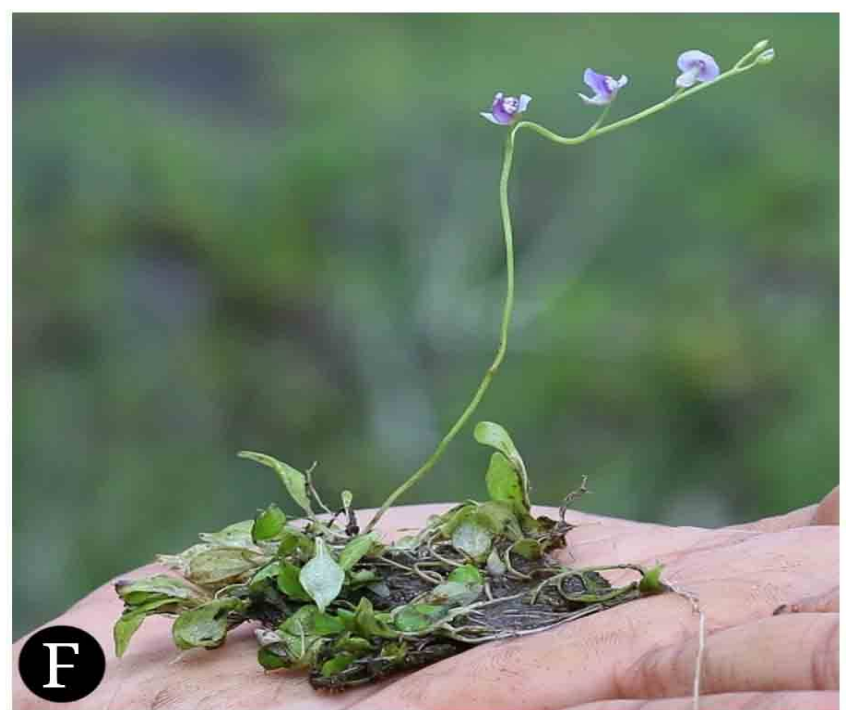

Habitat: It grows on wet rocks and sloppy wet grass lands from $100-800 \mathrm{~m}$ altitude. It is found associated with Utricularia reticulata Sm., Eriocaulon cinereum R. Br., Desmodium triflorum (L.) DC. and Eragrostis ciliaris (L.) R.Br.
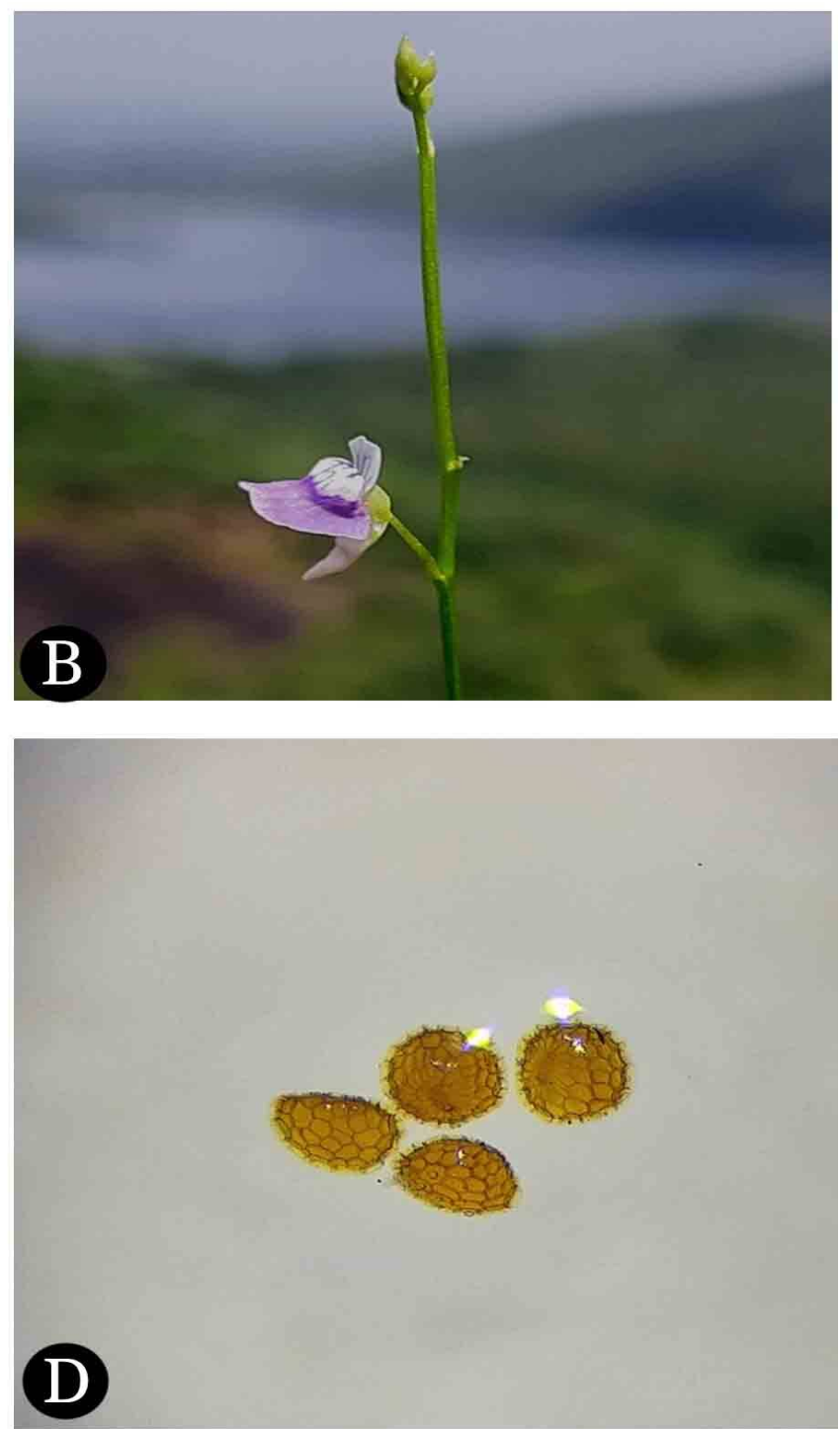
Distribution: Kolhapur and Satara districts of Maharashtra and Girnar hills, Junagadh district, Gujarat.

Specimen examined: Gujarat, Junagadh district, Girnar, Lal Dhori (2153' 83.15” N; 70 50’31.89” E). (BKNMU015).

Date of collection: 22/08/2020

Name of Collector: Kamlesh Gadhvi and Sandip Gamit, Herbarium of Department of Life Sciences, Bhakta Kavi Narsinh Mehta University, Junagadh, Gujarat.

\section{Acknowledgements}

The authors are grateful to Dr. M.M. Sardesai, Department of Botany, Savatribai Phule Pune University, Pune for confirming the species. We are also thankful to Mr. Bhurabhai Odedara (Agricultural assistant, Junagadh Agriculture University) for assisting in the field and Mr. Naman Doshi for capturing photographs.

\section{Authors' contributions}

KG, SG and RY had collected and identified the plant. SV and DD have prepared the manuscript for correspondence.

\section{Conflict of interests}

The authors don't have any competing interests.

\section{References}

1. Taylor P. The genus Utricularia - A taxonomic monograph. Kew Bulletin additional series XIV. Her Majesty's Stationery Office, London; 1989. p. 724.

2. Fleischmann A. The new Utricularia species described since Peter Taylor's monograph. Carnivorous Plant Newsletter
[Internet]. 2012 [cited 2020 November 15];41(2):67-76. Available from: https://cpn.carnivorousplants.org/articles/CPNv41n2p67_76.pdf

3. Arya S, Raju R, Arunraj PT, Vishnu WK, Biju P, Anilkumar VNS. Utricularia kamarudeenii (Lentibulariaceae): a new species from Kerala, India. Phytotaxa [Internet]. 2020 [cited 2020 November

https://doi.org/10.11646/phytotaxa.447.1.7

15];447(1):68-72.

4. Biju P, Josekutty EJ, Janarthanam MK, Jomy A. Utricularia sainthomia (Lentibulariaceae), a new remarkable carnivorous species from the lateritic plateau of northern Kerala, India Rheeda [Internet]. 2020 [cited 2020 November 16];30(2):27077. https://doi.org/10.22244/rheedea.2020.30.02.02

5. Janarthanam MK., Henry AN. Bladderworts of India. Botanical Survey of India, Kolkata; 1992. p. 174.

6. Kumar VVN, Prabhukumar KM, Jagadeesan R, Harinarayanan CM, Nair MC, Janarthanam MK, Balachandran I. Utricularia sunilii (Lentibulariaceae), a striking new species from southern Western Ghats, Kerala, India. Phytotaxa [Internet]. 2018 [cited 2020 November 16];371(2):140-44 https://doi.org/10.11646/phytotaxa.371.2.9

7. Yadav SR, Sardesai MM, Gaikwad SP. Two new species of Utricularia L. Lentibulariaceae) from Peninsular India. Rheedea [Internet]. 2000 [cited 2020 November 17]; 10:107-112. Available from: https://researchgate.net/publication/298378767_Two_new_spec ies_of_Utricularia_L_Lentibulariaceae_from_Peninsular_India

8. Yadav SR, Sardesai MM, Gaikwad SP. A new species of Utricularia L. (Lentibulariaceae) from the Western Ghats, India. Rheedea [Internet]. 2005 [cited 2020 November 15]; 15(1):71-73. Available from https://researchgate.net/publication/298378392_A_new_species_0 f_Utricularia_L_Lentibularaceae_from_the_Western_Ghats_India

9. Shah GL. Flora of Gujarat State. Sardar Patel University Press; 1978. p. 153-55.

10. Pandya IY, Salvi HD. Significance of tropical woods of Southern Gujarat. Laxmi Book Publication; 2017. p. 242.

11. Maitreya BB. Aquatic Angiosperms of Bor Talav (Gaurishankar Lake) Area of Bhavnagar City, Gujarat-India. International Journal of Scientific Research [Internet]. 2015 [cited 2020 November 25]; 4(6):p.680-82. Available from: https://www.worldwidejournals.com/international-journal-ofscientific-research-(IJSR)/recent_issues_pdf/2015/June/ June_2015_1434711003_218.pdf

12. Bole PV, Pathak JM. Flora of Saurashtra: Asteraceae to Casuarinaceae. Botanical Survey of India; 1988. p. 155-56. 